\title{
Measure Reasoning Skill of Mathematics Students
}

\author{
Jeinne Mumu ${ }^{1} \&$ Benidiktus Tanujaya ${ }^{1}$ \\ ${ }^{1}$ Department of Mathematics Education, University of Papua, Indonesia \\ Correspondence: Benidiktus Tanujaya, Department of Mathematics Education, University of Papua, Manokwari \\ 98314 West Papua, Indonesia. E-mail: b.tanujaya@unipa.ac.id
}

Received: August 23, 2019

Accepted: September 26, 2019

Online Published: September 27, 2019

doi:10.5430/ijhe.v8n6p85

URL: https://doi.org/10.5430/ijhe.v8n6p85

\begin{abstract}
The purpose of this research was to measure the reasoning skills of mathematics students using a test instrument developed from mathematics routine and non-routine task. The study used research and development method. Development of the instrument and measurement of mathematical reasoning skills using procedure: items preparation (modification task), expert validation, field testing, and data analysis. The field testing involves students of senior high school (SMA Negeri 1) and students of University of Papua, Manokwari West Papua Indonesia. The data analyzed through studying the students' task solving, the transcripts of their work, interview after the test, identifying the specific task solving situations, and the arguments were supporting the strategy choice and strategy implementation. Result of research shows that student mathematical reasoning can be measured using the instrument test developed from the routine task and non-routine task. This research classifies the reasoning skills of mathematics students into two categories, imitative reasoning, and creative reasoning. Reasoning skills of mathematics students grouping results can be used by various interested institutions to evaluate the test using in mathematics instruction.
\end{abstract}

Keywords: mathematics reasoning, reasoning skills, imitative reasoning, creative reasoning, routine task and non-routine task

\section{Introduction}

Mathematics is a subject directly related to human life. The subject has emerged from humans' observation of the world (Tanujaya, Prahmana, and Mumu, 2017). Since ancient time, mathematics guided human beings in tackling real-world problems, providing powerful tools for the development of sciences. Nowadays, mathematics still plays a crucial role in almost every branch of science and technology (Miao and Reynolds, 2018). The importance of mathematics makes it essential that children be well educated on the subject. Therefore, students who study mathematics need to know how to learn mathematics appropriately.

Learning mathematics is somewhat different from learning other subjects. The student who studied mathematics must think and learn mathematics by/for themselves (Masami, 2012; Tanujaya, 2014; Mumu and Tanujaya, 2018), must think mathematically (Tanujaya, 2016), and have to feel free to explore the intended knowledge independently with minimal formal teaching input (Miao and Reynolds, 2018). Mathematical thinking is different from doing mathematics. Students need to explore their thinking abilities when learning mathematics.

On the other hand, mathematics instruction that teaches and supports students' thinking skills in Indonesia, especially in West Papua Province is still rare (Tanujaya, Prahmana, and Mumu, 2017). Impact of the situation can be seen from the low mathematics achievement of Indonesian students. Indonesian students are always ranked low on various international tests, for example, PISA results with an average of 386 mathematical scores, or rank 63 of 70 countries (OECD, 2018), and TIMSS with an average mathematical score of 397, rank 45 out of 50 countries (TIMSS, 2016). Therefore, a revision in Indonesian mathematics instruction is urgent.

Mathematics instruction, as well as other instruction in education, is an attempt to humanize human beings. Therefore, it must be a successful instruction. The success of mathematics instruction can be measured by various indicators, one of which is through the student learning outcomes. A successful educational system should focus on student learning outcomes and provides the support necessary for every student to achieve them (Sutton and Krueger, 2002). The students' mathematics learning outcome is a form of mathematical concepts understanding that is very important in mathematical instruction (Mumu, Prahmana, and Tanujaya, 2018), that needs to be known by the teacher as well as by the students themselves, using assessment. 
Assessment, especially classroom assessment, is not only designed to determine the rank and grade of students but more importantly, to get other functions in the learning process (Tanujaya, 2017). The assessment has traditionally been used to evaluate student's accomplishment and content area of curriculums. However, new approaches to mathematics instruction have expanded the role of the assessment to include supervising student improvement and making instructional decisions (Sutton and Krueger, 2002). The teachers can find out the information in a variety of classroom assessments that range from observations and discussions to test, tasks, and projects, from self-assessment and homework to oral presentations (De Lange, 1999).

The assessment has various purposes, such as providing student grades, system monitoring, student placement, determining interventions, improving teaching and learning, or offering individual feedback to students and their parents (Newton, 2007). The assessment is also a process of gathering the information that accurately reflects how well a student is achieving the curriculum expectations in a subject (OME, 2010). The result of learning evaluation by the teacher can also be used by students to support their success of learning. The assessment can help students monitor their studying. When students know what is expected of them, through feedback and grading criteria, they are better able to keep track of their mastery of the material (Sutton and Krueger, 2002). The assessment should be an integral part of the learning process (De Lange, 1999). Thus, there are some purposes of mathematics classroom assessment, although the primary purpose of the assessment is basically to improve the achievement of student learning.

The mathematics classroom assessment is a primary instrument for supporting and monitoring student progress toward mathematics standard (Sutton and Krueger, 2002). Teachers should know about their students' problems while learning their progress, and the level of formality they are operating at so that they can adapt their teaching strategies to meet the students' needs (Mumu, Prahmana, and Tanujaya, 2018). Thus, practical assessment in mathematics requires more than a look at the answers students give. The teachers need to analyze their processes and get the student to communicate mathematical thinking (Szetela and Nikol, 1992). The ability to think mathematically is the most crucial aspect of learning mathematics.

In order to evaluate the thinking ability of students who study mathematics, it is necessary to know the components in students' thinking skills, especially students who study mathematics. According to Breen and O'Shea, one level of mathematics learning outcomes is the students' reasoning ability. The reasoning is one mathematical thinking skills in addition to conjecturing, proving, making connections, abstraction, generalization, and specialization (Breen and O'Shea, 2011). Being able to reason is essential to understanding mathematics (NCTM, 2000).

Mathematics reasoning is the process of making sense of and understanding mathematical ideas and concepts inherent to procedures (Bieda et al., 2013), the line of thought adopted to produce assertions and reach conclusions (Boesen, Lither, and Palm, 2010), and can be defined as five interrelated processes of mathematical thinking, categorized as sense-making, conjecturing, convincing, reflecting, and generalizing (Blujand, 2007), Conjecturing is forming an opinion or supposition about (something) on the basis of incomplete information. Convincing is causing (someone) to believe firmly in the truth of something, reflecting is thinking profoundly or carefully about, while generalizing is make a general or broad statement by inferring from specific cases or make (something) more widespread or prevalent.

Students use reasoning when they engage in mathematical argumentation, is a process that involves making and justifying mathematical claims (Bieda et al., 2013). Argumentation is the substantiation, the part of the reasoning that aims at convincing oneself or someone else that the reasoning is appropriate (Boesen, Lither, and Palm, 2010). The students tend to note patterns, structure, or regularities in both real-world situations and symbolic objects. They ask if those patterns are accidental or if they occur for a reason, and they conjecture and prove (NT, 2000). It is, therefore, essential for a mathematics teacher to have an instrument to measure mathematics students' reasoning skills.

Students' thinking skills in mathematics reasoning possess two categories: Imitative Reasoning (IR), and Creative Mathematically founded Reasoning (CMR) (Lithner, 2007; Bergqvis, 2007). Imitative reasoning is also known as Memorized Reasoning (MR) and Algorithmic Reasoning (AR). Imitative reasoning is students reasoning that often suitable in routine tasks. The MR strategy choice is founded on recalling, by memory, an answer, and the strategy implementation consist only of writing it down. The AR strategy choice is to recall an algorithm, which is a sequence of rules for solving a particular task type whereas the three following conditions define CMR, i.e., novelty, plausibility, and mathematical foundation (Boesen, Lither, and Palm, 2010). Thus, there are five levels of mathematical reasoning skills, as shown in Figure 1 below. 


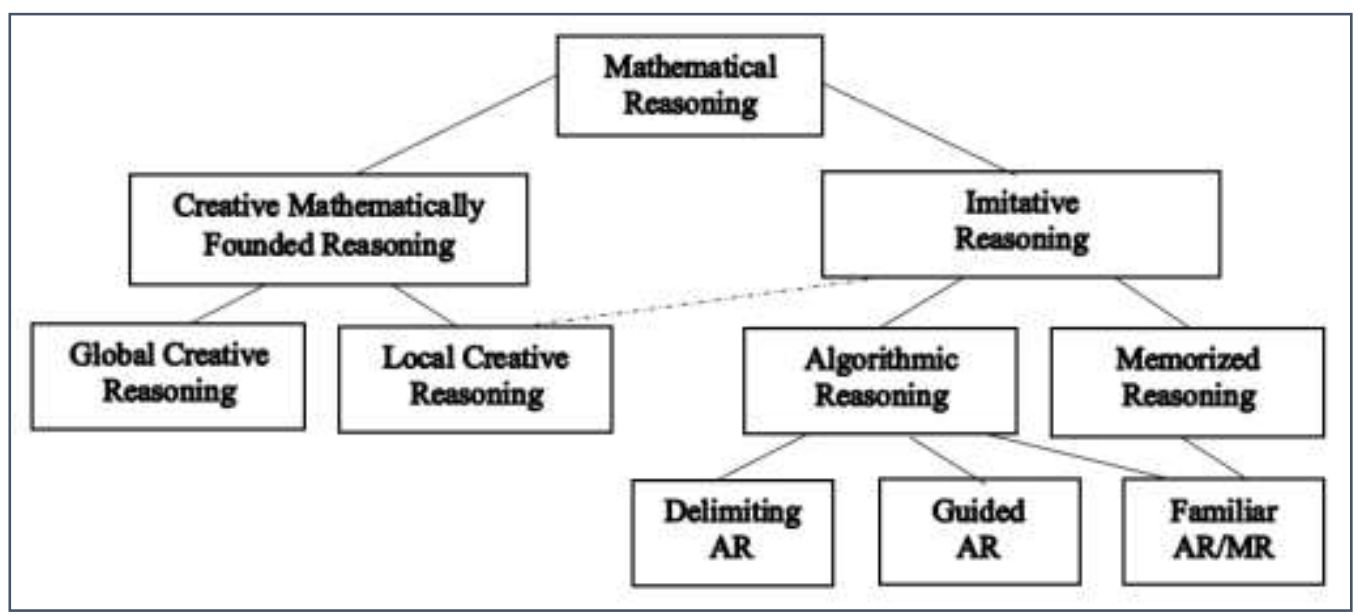

Figure 1. Overview of mathematics reasoning of mathematics students in the framework

Furthermore, studies have shown that many teacher-made task display a heavy focus on Imitative Reasoning only (Bergvis, 2007; Boesen, Lither, and Palm, 2006). Likewise, the assignment compiled by mathematics teachers in Manokwari, and the assignment in the textbooks they use, are generally routine task in the range C1 - C3 (Tanujaya, Prahmana, and Mumu, 2017; Yenusi, Tanujaya, and Mumu, 2019), which can be grouped in the matter of Imitative Reasoning.

How can the teacher measure students' reasoning skills if the task available are only in the group of imitative reasoning? Therefore, in order to measure mathematical reasoning skill of students in Indonesia, especially in West Papua, it is necessary to develop the non-routine test. The non-routine test can be developed from various tests in mathematics textbooks or the mathematics Olympiad. So, the purpose of this research was to measure the reasoning skills of mathematics students using test instrument developed from mathematics routine and non-routine task.

\section{Methods}

The method used in this study is research and development (R\&D). R\&D is a research method to achieve new knowledge that it might use to create new technology, products, services, or systems. Thus, the results of this research are a test of mathematics instrument to measure the ability of reasoning skills of mathematics students, especially for high school students and first-level of university students. The instrument test used as a reference for developing similar test instruments.

The research, development of test instrument, was conducted in four steps, i.e., item preparation (modification task), expert validation, measurement of student reasoning skills (field testing), and data analysis. Test instrument development was started by compile some types of mathematics task from some sources. The task consists of familiar and unfamiliar problems for students. The familiar problems were taken from the mathematics textbook, while the unfamiliar problems are a task from mathematics Olympics and modified from both types of tests. The familiar tasks are also known as routine tasks, while unfamiliar tasks referred to as non-routine tasks.

The instrument tests development continued with item analyzed by experts to determine the familiarity level of the items. The experts also conducted an analysis of the readability and social desirability of the item. Each expert had discussed with an others expert to then deducing their decision. The expert analysis results were used by the researcher to compose some new test instruments. The analysis conducted by these experts is an effort to increase the validity of the instrument. The experts' judgement of instrument items is referred to as content validity. Content validity according to Rusticus, refers to the degree to which an instrument is relevant to, and representative of, the targeted construct it is designed to measure (Rusticus, 2014).

The measurement of reasoning skills involves 20 students from senior high school (SMA Negeri 1) in Manokwari and 30 students from mathematics education department, the University of Papua in Manokwari, West Papua Indonesia. High school student are students majoring in natural sciences, while the university students are students of mathematics education, University of Papua.

Data analysis in this study consists of two phases. The first thing was to interpret the reasoning skills of mathematics students by studying the students' task solving, using transcripts of their work and the interview. The second phase of data analysis was to identify the crucial task solving situations, and the arguments supporting the strategy choice and strategy implementation. Based on the characteristics of these argumentations, each solution attempt was classified 
as comprising one of the reasoning types in the framework (see fig. 1) (Boesen, Lither, and Palm, 2006).

\section{Results and Discussion}

In classroom activities when solved the task, the students provided a complex reaction in working solving a non-routine problem of mathematics. Several responses revealed how students have difficulty in solving the non-routine task. Majority students, however, expressed the view that despite some difficulty of the subject, they were able to accomplish and provide solutions to the problems. There are three cases of solutions to the student.

Case number one, the students can answer the task correctly. However, the answer presented does not show a detailed completion process. The answer given is the result of remembering what the teacher teaches. The students memorize how to get the answer. This remembering activity belongs to a low level of reasoning. The students tend not to use mathematical reasoning skills when solving the task. According to Bieda et al., students use reasoning when they engage in mathematical argumentation (Bieda et al., 2013). When solving this type of task, students do not fully use their reasoning skills. They do not show arguments that should appear in their answers. The students' reasoning abilities do not appear in their responses.

The students' mathematical reasoning ability in this group classified into two groups: memorized reasoning and algorithm reasoning. The answers given by the first group of students are the result of the process of memorization, while in the second group of students, the answers were obtained using the learned procedure - these two groups of students classified into imitative reasoning. Imitative reasoning, according to Bergqvist, can be described as a type of reasoning built on copying task solutions. They found the way of solutions from a textbook example or through remembering an algorithm or an answer. Some observations show a connection between a narrow focus on imitative reasoning and students' difficulties when learning mathematics (Bergvis, 2007).

However, at the time of the interview, the students can generally show how to solve the problem. An example on the issue is to determine the value of the multiplication of two integers. All students can quickly answer the question. However, they could not elaborate on how they got the answer. Some of them using distributive law of addition to solves the problems. Others can answer after the researchers helped them explore the concept they have learned. The concept is known through memorization, not through understanding the concept well.

Therefore, mathematics task should present in the form of open questions. The kind of tasks can develop students' mathematics reasoning skills because inquiring about mathematics concepts. For example, show that 12 × $8=96$ ? This type of task question should provide to students who study mathematics, more specifically about the concept of multiplication. Since elementary school, students are generally required to memorize the results of multiples of two integers, without knowing how to get it. This situation enforces mathematics teachers to teach the concept of multiplication correctly.

Experts classified these types of questions as open-ended questions. The question is a problem whose solution solves in various approaches. The questions require more thought and more than a simple one-word answer. This type of problem causes students to think about solving the problem.

Teachers play a crucial function in developing students' reasoning abilities. Student reasoning ability can be done in various ways, one of which is through habituation in learning. Students should be accustomed early to be able to solve mathematical questions that require thinking skills. Therefore, the questions contained in various mathematics textbooks should be developed and modified by the teachers before being used in mathematics learning.

Some research showed that examples of questions and practice questions contained in mathematics textbooks used by mathematics teachers in Manokwari, West Papua, are mostly only questions categorized as low-level thinking skills (Tanujaya, et. al., 2017; Yenusi, et. al., 2019). The cognitive domain of c1 - c3 or low-level thinking skills is classified as low order thinking skills - LOTS. Whereas, the cognitive area of $\mathrm{c} 4-\mathrm{c} 6$ is classified as a higher-order thinking skill (Tanujaya, 2016; Tanujaya, et. al., 2016; Moore \& Stanly, 2010).

Mathematics instruction has characteristics that are not the same as the characteristics of other lessons. Therefore, example and practice problems used in the instruction of mathematics should use HOTS questions. The used of HOTS questions in learning mathematics can improve students' thinking skills well. Students who have excellent thinking skills will able to solve problems both problems in school, as well as problems in daily life, now and later on (Tanujaya, et. al., 2016).

The second case, students' answers are varied, depending on the known mathematical concepts, their ability to remember the concepts that have been mastered, and how to use the mathematical concepts. The variety of students' answers shows the diversity of their mathematical reasoning skills. 
For example, prove that the number of angles of a triangle is 180 degrees.

In this case, only a small percentage group of students can solve the task correctly. Others are generally confused about how to answer the question. They have no idea how to solve it. They have never done such a mathematics problem. They are not accustomed to working on problems that are not routine, so they have no idea how to answer it. So, the types of problems are classified as a non-routine task.

A non-routine task is a complicated question that could be solved in several procedures, but typically do not have an immediately apparent approach for solving it. Student requires some degree of creativity or originality to solves the problem (George, 2005; Melissa, 2015). The types of problems focus on developing students' mathematical reasoning and fostering the understanding that mathematics is a creative subject matter. Solving the non-routine problems in mathematics intensifies their study habit, actualizes their creative skill, improves their strategic thinking skill, and develops their focus and mental discipline. Conversely, the task discourages them because it is highly challenging, mentally, and physically exhausting, and, lastly, their experience with the teacher is frustrating (Daguplo, 2013).

In the group of students who answered correctly, their answers were quite diverse. There are several versions of solutions performed by students. The diversity of answers occurs because of the variety of concepts used in answering the problems. The ability of students to use the various concepts that have been learned is crucial in answering these tasks. In this case, students who answered correctly are classified as students who have good mathematics reasoning ability. In the first group, the students were able to solve the task because they had worked on a similar task. They use algorithms and basic techniques that have been studied to answer the various exam.

Furthermore, in the second group of students, they have never worked on that type of task. They develop their reasoning skills, using various concepts that have been studied. Both groups of students can be categorized as students who have creative mathematically founded reasoning. Creative mathematically founded reasoning is a product of creative mathematical thinking. Creativity is not primarily correlated to geniality or superior thinking, but the creation of a new and reasonably well-founded task answer (Bergvis, 2007).

The Final Case, almost all students cannot answer the task questions correctly. The main reason given by students is that this type of task never been taught before; they have no idea. The last tasks are classified as a non-routine task. These kinds of problems are hardly used in routine mathematics learning activities, so students do not know how to solve them.

Why does this happen? Tanujaya, et al., showed that in general, the Indonesian students are not accustomed to thinking in learning mathematics. Conversely, in learning mathematics, students have to think, thinking mathematically (Tanujaya, et al., 2017). Students must be able to do reasoning when solving mathematics problems. The reasoning is a thinking process, as the product of these processes, or both (Lithner, 2007). Thinking is an essential process in learning mathematics (Tanujaya, 2014; Mumu and Tanujaya, 2018; Haryono \& Tanujaya, 2018; Drupadi \& Mumu, 2018).

\section{Conclusion}

Student's mathematical reasoning can be measured using the instrument test developed from the routine and non-routine task. The result of the measurement shows that there are two kinds of mathematics students' reasoning can be grouped into two, that is students who memorize, and using the algorithm, classified as students who have imitative reasoning, while the students who develop the concept, and creates the procedure to solve mathematical problems as creative reasoning students. The results of these measurements can also be used to perform the detection of errors in the learning of a mathematical concept, to improve the quality of mathematics instruction.

\section{References}

Bergqvis, E. (2007). Types of reasoning required in university exams in mathematics. Journal of Mathematical Behaviour, 26(2007), 348-370. https://doi.org/10.1016/j.jmathb.2007.11.001

Bieda, K. N., Ji, X., Drwencke, J. \& Picard, A. (2013). Reasoning and proving opportunities in elementary mathematical textbook. International journal of educational research. https://doi.org/10.1016/j.ijer.2013.06.005

Bjuland, R. (2007). Adult Students' Reasoning in Geometry: Teaching Mathematics through Collaborative Problem Solving in Teacher Education. The mathematics enthusiast, 4(1), 1-30.

Boesen, J., Lithner, J. \& Palm T. (2006). The relation between test task requirements and the reasoning used by students - An analysis of an authentic national test situation, Department of Mathematics Ume a University. 
Boesen, J., Lithner, J. \& Palm, T. (2010). The relation between types of assessment tasks and the mathematical reasoning students use. Educ Stud Math, 75, 89-105. https://doi.org/10.1007/s10649-010-9242-9

Breen, S. \& O'Shea, A. (2011). The use of mathematical tasks to develop mathematical thinking skills in undergraduate calculus courses - a pilot study, in Smith, C. (Ed.) Proceedings of the British Society for Research into Learning Mathematics, 31(1), March 2011.

Daguplo, M. S. (2013). Non-routine mathematics problem: Phenomenological analysis positive and negative learning impact. Journal education and human resource development, 1(2013), 46 - 58.

De Lange, J. (1999). Framework for classroom assessment in mathematics. Freudenthal Institute and National Center for improving student learning and achievement in mathematics and science.

Drupadi S W \& Mumu, J. (2018). Analisis kemampuan penalaran induktif matematis mahasiswa pendidikan matematika universitas papua. Journal of Honai Math, 1(1), 113-126. https://doi.org/10.30862/jhm.v1i2.1048

George (2005). Creative problem-solving in school mathematics. Bellmore, New York: Mathematical Olympiads for elementary and middle schools, Inc.

Haryono A \& Tanujaya, B. (2018). Profil kemampuan penalaran induktif mahasiswa pendidikan matematika unipa ditinjau dari gaya belajar. Journal of Honai Math, 1(2), 127-138. https://doi.org/10.30862/jhm.v1i2.1049

Lithner, J. (2007). A research framework for creative and imitative reasoning. Educ. Stud, 67, 255-276. https://doi.org/10.1007/s10649-007-9104-2

Masami, I. (2012). Problem Solving Approach to Develop Mathematical Thinking, Monographs on Lesson Study for Teaching Mathematics and Sciences - Vol. 1. https://doi.org/10.1142/9789814350853_0001

Melissa (2015). Problem-solving in math retrieve from thhps://teacherthrive.com/2015/09/non-routineproblem-solving.html

Miao, Z. \& Reynolds, D. (2018). The effectiveness of mathematics teaching in primary schools: Lessons from England and China, NY: Routledge. https://doi.org/10.4324/9781315563763

Moore B \& Stanly, T. (2010). Critical thinking and formative assessment. Larchmount, New York: Eye on Education, Inc

Mumu J, Prahmana R. C. I. \& Tanujaya, B. (2018). Construction and reconstruction concept in mathematics education. J. Phys.: Conf. Ser, 943, 012011. https://doi.org/10.1088/1742-6596/943/1/012011

Mumu J \& Tanujaya, B. (2018). Desain pembelajaran pateri operasi pada himpunan menggunakan permainan "Lemon Nipis". Journal of Honai Math, 1(1), 14-23. https://doi.org/10.30862/jhm.v1i1.770

NCTM (2000). Principles and standards for schools' mathematics, The national councils of teachers of mathematics.

Newton, P. E. (2007). Clarifying the purposes of educational assessment. Assessment in Education: Principles, Policy, and Practice, 14(2), 149-170. https://doi.org/10.1080/09695940701478321

OECD. (2018). PISA 2015 results in focus OECD.

OME. (2010). Growing Success: Assessment, Evaluation, and Reporting in Ontario School. Ontario: The Ministry of Education's

Rusticus, S. (2014). Content Validity. Encyclopedia of Quality of Life and Well-Being Research, 1261-1262. https://doi.org/10.1007/978-94-007-0753-5_553

Sutton J. \& Krueger, A. (2002). EDThought: What we know about mathematics teaching and learning.

Szetela, W. \& Nikol, C. (1992). Evaluating problem-solving in mathematics, Educational Leadership, May 1992, $42-45$.

Tanujaya, B. (2014). Pengukuran Keterampilan Berpikir Kritis Siswa SMA dalam Pembelajaran Matematika. Proceeding Seminar Nasional Psikometri, Universitas Muhammadiyah Surakarta.

Tanujaya, B. (2016). Development of an instrument to measure higher-order thinking skills in senior high school mathematics instruction. Journal of education and practice, 7(21), 144-148.

Tanujaya, B. (2017). Application of assessment as learning in mathematics instruction. Proceeding of the $5^{\text {th }}$ southeast Asia development research, 140-143. https://doi.org/10.2991/seadric-17.2017.30 
Tanujaya, B., Mumu J. \& Margono, G. (2017). The relationships between higher order thinking skills and academic performance of student in mathematics instruction. International Education Studies, 10(11), 78-85. https://doi.org/10.5539/ies.v10n11p78

Tanujaya, B., Prahmana, R. C. I. \& Mumu, J. (2017). Mathematics instruction, problems, challenges, and opportunities: A case study in Manokwari regency, Indonesia. World Transactions on Engineering and Technology Education, $15,287$.

TIMSS. (2016). TIMSS International Result in Mathematics. TIMSS \& PIRLS International Study Center.

Yenusi, T., Tanujaya, B. \& Mumu, J. (2019). Analisis soal latihan pada buku paket matematika SMA yang bersesuaian dengan higher order thinking skill. Journal of Honai Math, 2(1), 53-64. https://doi.org/10.30862/jhm.v2i1.58 